\title{
TRWAĆ W JĘZYKU PRZYPADEK STANISŁAWA WYGODZKIEGO
}

\author{
Monika SZABLOWSKA-ZAREMBA (Katolicki Uniwersytet Lubelski Jana \\ Pawła II) \\ ORCID: 0000-0002-2064-1943
}

Milczenie jest w moich warunkach czymś zupełnie nieznośnym: staje się ono wieloznaczące i trapiące. Żyję daleko od ludzi, mam dużo powodów do rozgoryczenia ${ }^{1}$.

Słowa te w 1973 r., po pięciu latach życia na emigracji, skierował do Stefanii Kossowskiej, redaktorki londyńskich „Wiadomości”, Stanisław Wygodzki, prozaik, poeta, tłumacz, mieszkający wówczas w Giwataim, w słonecznej dzielnicy w Tel Awiwie, gdzie zamiast ciszy, spokoju i wolności towarzyszyła mu samotność oraz poczucie przegranej.

Biografia Wygodzkiego wpisała się w wydarzenia historyczne XX w. Jako dziecko przeżył pierwszą wojnę światową, jako dorosły doświadczył tragedii Zagłady. W kwietniu 1947 r. powrócił po wojennej gehennie do Polski. Dwadzieścia jeden lat później, 31 stycznia 1968 r. — pisarz wysiadł z samolotu na lotnisku w Izraelu i poczuł, że wcale nie chciał być tam, gdzie właśnie się znalazł. Każde z tych zdarzeń, zdawałoby się, odnosiło się do innego rodzaju doświadczenia egzystencjalnego, lecz jednocześnie każde z nich konotowało stratę, wykluczenie oraz poczucie obcości.

$\mathrm{Z}$ racji objętości tekstu zawężę swoje uwagi do ostatniego z przywołanych okresów, choć wszystkie związane są ze sobą nierozerwalnymi nićmi zależności przyczynowoskutkowych. Ich złożoność dokładniej przedstawiam w monografii, poświęconej życiu i twórczości Stanisława Wygodzkiego. Teraz chciałabym przybliżyć etap najmniej rozpoznany w odniesieniu do działalności twórczej pisarza. Pierwszych prób opisu emigracyjnej spuścizny Wygodzkiego podjęli się Karolina Famulska-Ciesielska oraz Kazimierz

\footnotetext{
${ }^{1}$ Archiwum Emigracji Biblioteki Uniwersyteckiej w Toruniu (dalej AE), Archiwum „Wiadomości”. Korespondencja, sygn. AE/AW/CCCXLVII, list Stanisława Wygodzkiego do Stefanii Kossowskiej z 15 września 1973.
} 
Adamczyk $^{2}$, chociaż jego twórczość stanowiła jedynie niewielką część ich obszernych badań. Warto zatem dokładniej zaprezentować ją polskiemu czytelnikowi ${ }^{3}$.

\section{Przyswajanie Izraela}

Wygodzki pragnął wpisać się w nowe środowisko literatów. Jego przybycie do Tel Awiwu wzbudziło różne emocje wśród krytyków, pisarzy oraz czytelników: od entuzjastycznych braw po ironiczne komentarze nieszczędzące mu uwag jako byłemu partyjnemu pisarzowi. Wygodzki starał się wejść w hebrajski obieg literacki, lecz pojawiły się dwie przeszkody.

Na łamach jednego z największych dzienników, wychodzących w języku polskim, „Nowiny i Kurier”, oficjalnie powitano go w nowej ojczyźnie. W notatce pt. Pisarz Stanistaw Wygodzki przybyt do Izraela jako nowy ole ${ }^{5}$ - przedstawiony został jako jeden z najbardziej popularnych twórców w Polsce, co prawda komunizujący, ale dla którego utrwalanie doświadczenia Zagłady w polskiej literaturze było najważniejszym zadaniem. Poza tym zaznaczono jego rolę jako thumacza utworów z języka jidysz, ze wskazaniem, że jego opowiadania również zostały przetłumaczone na ten język ${ }^{6}$. Całość zamknęło zapewnienie, że w Izraelu przebywają dwie siostry żony pisarza, a on sam w przyszłym tygodniu otrzyma oficjalny dokument potwierdzający prawo do osiedlenia się w Izraelu. Od nr 39., tj. od 14 lutego regularnie do kwietnia, na pierwszej stronie dziennika zamieszczano informacje o kolejnych wieczorach autorskich Wygodzkiego organizowanych w Tel Awiwie, w Jerozolimie czy w Hajfie. W anonsach zapewniano, że w czasie tych spotkań pisarz zaprezentuje m.in. fragmenty powieści rozrachunkowej Zatrzymany do wyjaśnienia, której druk w Polsce był zakazany ${ }^{7}$, a także porozmawia $\mathrm{z}$ publicznością. $\mathrm{W}$ ten sposób Wygodzki zyskiwał poczucie bycia użytecznym oraz bronił się przed myślą utraty kontaktu z polskojęzycznym czytelnikiem. Zapowiedzi o wieczorach literackich $\mathrm{z}$ udziałem pisarza zaczęto również za-

${ }^{2}$ K. Famulska-Ciesielska, Polacy, Żydzi, Izraelczycy. Tożsamość w literaturze polskiej w Izraelu, Toruń 2008; K. Adamczyk, Doświadczenia polsko-żydowskie w literaturze emigracyjnej (1939-1980), Kraków 2008.

${ }^{3}$ Artykuł ten powstał dzięki grantowi D, przyznanemu we wrześniu 2019 r. na Wydziale Nauk Humanistycznych Katolickiego Uniwersytetu Lubelskiego (dziedzina: Literaturoznawstwo).

${ }^{4}$ Dziennik powstały po zjednoczeniu dwóch czasopism „Nowin” i „Kuriera” wydawany był w Tel Awiwie w latach 1968-1992 jako gazeta codzienna, a w latach 1992-2009 jako tygodnik. Reprezentował dwa stronnictwa: Partię Postępową i Mapaj; zob. więcej: E. Kossewska, Ona jeszcze mówi po polsku, ale śmieje się po hebrajsku, Warszawa 2015, s. 199-280.

${ }^{5}$ Tym mianem określano emigrantów przybyłych do Izraela z zamiarem osiedlenia się tu na stałe. Liczba mnoga tego wyrazu: olim.

${ }^{6}$ Anonim, Pisarz Stanisław Wygodzki przybyt do Izraela jako nowy ole, Nowiny i Kurier $1968 \mathrm{nr}$ 31, s. 2. Nastąpiła tu pomyłka, gdyż artykule podano, że opowiadania Wygodzkiego w języku jidysz ukazały się w 1964 r. Autor miał zapewne na myśli jeden ze zbiorów opowiadań: Koncert życzeń - Der wincz-koncert, który wydano w 1960 r. w serii Mała Biblioteka nr 7 lub Dokad oczy poniosq — Wu di ojgn trogn (1963), przekładu obydwu dokonał D. Sfarda, obydwa też ukazały się w warszawskim wydawnictwie Idisz-Buch.

${ }^{7}$ Powieść rozliczała się z okresem stalinowskim. Była drukowana na łamach dwóch numerów „Twórczości” w 1957 r., z powodu cenzury zniszczono cały nakład. Wyjeżdżając z Polski, Wygodzki miał tylko jeden jej rękopis. W 1968 r. wydano ją w paryskiej „Kulturze”. Równolegle ukazała się w tłumaczeniu na język hebrajski i wkrótce niemiecki. 
mieszczać na łamach „Przeglądu Izraelskiego"8, pisma, które jako pierwsze zaprosiło go do współpracy. Jednak dość szybko ten błogi stan został przerwany. 4 kwietnia 1968 r. pisarz uległ wraz z przyjaciółmi wypadkowi samochodowemu. Nieobecność w obiegu kulturalnym, spowodowana długim pobytem w szpitalu i rehabilitacją, przekreśliła zawodowe plany oraz mocno ostudziła zainteresowanie jego osobą w środowisku kulturalnych elit. Powrócił do nich już nie jako pisarz polityczny, lecz jako twórca dzieł o Zagładzie, czego wyrazem są dwie nagrody, jakie otrzymał: w 1969 r. — nagrodę Związku byłych Więźniów Bergen-Belsen ${ }^{9}$ oraz w 1971 r. — państwową nagrodę im. prezydenta Zalmana Szazara.

Podstawową przeszkodą, która uniemożliwiła mu zaistnienie w świadomości hebrajskich czytelników, okazał się język, dzięki któremu pisarz określa swoją tożsamość. Dla Wygodzkiego takim był polski. Kazimierz Adamczyk, opisując polskożydowskie doświadczenia w literaturze emigracyjnej, porównał losy trzech emigrantów: Wygodzkiego, Arnolda Słuckiego oraz Filipa Istnera:

Jako miejsce osiedlenia wybrali początkowo Izrael. Do końca życia pozostał w nim jedynie Wygodzki. Tylko Słucki znał język hebrajski, a Istner w wieku lat sześćdziesięciu rozpocząl jego naukę ${ }^{10}$.

Nie jest to w pełni prawdą. Wygodzki znał od dzieciństwa język hebrajski z uwagi na to, że jego ojciec, Izaak Wolf Wygodzki, był jednym z najbardziej aktywnych działaczy syjonistycznych w Zagłębiu Dąbrowskim i zapewne jego największym marzeniem było, aby synowie wyjechali do Erec Israel - nowego państwa żydowskiego. Pisarz uczęszczał również do gimnazjum hebrajskiego w Będzinie. W stworzonym specjalnie dla Mordechaja Hampla ${ }^{11}$ biogramie, wymienił „świętych żydowskich nauczycieli”: Sobótkę, Aleksandra Zyskinda, Borensztajna, a także krawca Tejweła: „który był bibliotekarzem w domu Żmigroda na ulicy Kołłątaja, zwaną niegdyś po żydowsku «di ałte gas»" "12. Proporcjonalnie do rosnącego w nim zaangażowania w działalność komunistyczną, Wygodzki odszedł od języka hebrajskiego, lecz nigdy go nie zapomniał. Choć po przyjeździe do Tel Awiwu przez kilka miesięcy wspólnie z rodziną przeszedł obowiązkowy kurs jego nauki i dość sprawnie w życiu codziennym się nim posługiwał, to nigdy nie mógł w nim tworzyć. Podkreślał to wielokrotnie m.in. w wywiadach udzielanych dziennikarzom izraelskiej prasy. W jednym z nich, opatrzonym dość zna-

8 „Przegląd Izraelski”, tygodnik społeczno-kulturalny. Ukazywał się od 1949 r. jako „Przegląd Wydarzeń w Izraelu”. W latach 1960-1982 funkcjonował pod nazwą „Przegląd Izraelski” lub „Przegląd”. W latach 70. z pismem byli związani m.in. Krystyna Bernard, Alicja Grabowska i Stanisław Wygodzki. Drukowano utwory literackie Efraima Kishona, Juliana Tuwima i Icchaka B. Singera.

9 Wedle informacji prasowej nagroda była wartości 2.5 tys. dolarów, co zapewne bardzo Wygodzkiemu pomogło w zapewnieniu godnej egzystencji jako osobie nieposiadającej stałego zatrudnienia; zob.: Anonim, \$2,500 Memorial Award given by Bergen-Belsen Group to new Polish immigrant in Israel, JTA Daily News Bulletin 1969 nr 125, s. 3.

${ }^{10} \mathrm{~K}$. Adamczyk, Doświadczenia polsko-żydowskie w literaturze emigracyjnej, s. 153.

11 Mordechaj Hampel, jeden z wydawców Pinkes Bendin [Księgi Będzina], drugim był A. Sh. Stein (Tel Aviv 1959).

12 di ałte gas (jid.) - stara ulica. Dom Żmigroda — kamienica przy ul. Kołłątaja 37 należąca do Dawida Żmigroda; Archiwum Pisarzy Hebrajskich w Tel Awiwie, Wigodski, Yehoshua, Makhon Gnazim, Tel Aviv, 118, 69252, List Ireny Wygodzkiej do Mordechaja Hampla z 10 czerwca 1958 . 
miennym tytułem Ostatni przystanek, prowadzący rozmowę dziennikarz z „Maariv”, Mosze Dor, zauważył:

Mówi [Wygodzki] po hebrajsku, powoli, ale prawie bezbłędnie i tylko od czasu do czasu, gdy chce wyrazić bardziej złożoną myśl lub użyć jakiegoś powiedzenia, którego mu brak w hebrajskim, przechodzi na język polski, i wtedy potrzebujemy pomocy wspólnego znajomego, który przetłumaczył dzieła Wygodzkiego na hebrajski ${ }^{13}$.

Należy dodać, że niekiedy w swoją wypowiedź pisarz wplatał pojedyncze słowa z języka jidysz, co zostało odznaczone w nawiasach w druku. Były one tak samo pomocne, jak słowa w języku polskim - miały oddać emocje, których pisarz nie potrafił zwerbalizować w języku hebrajskim. Opowiadając o swoim miejscu w Izraelu, dodał:

Rozumiem wszystko po hebrajsku, dlatego chodzę na wykłady do Domu Sokołowa i Domu Pisarza, chociaż gdybym znał lepiej hebrajski, związek byłby bardziej żywy. Jest to przeszkoda — przypuszczam — nie tylko dla mnie. Ale bez trudu czytam po hebrajsku, codziennie czytam hebrajską gazetę. Jednak Agnona ${ }^{14}$ czytałem w jidysz i po niemiecku - nie byłem w stanie go przyswoić po hebrajsku. W jidysz był mi bliższy ${ }^{15}$.

Wygodzki został przyjęty do Związku Pisarzy Hebrajskich i Hebrajskiego PEN Clubu. Niemniej oglądając bardzo skromną dokumentację, przechowywaną w archiwum na temat Wygodzkiego, można domniemywać, że nie odegrał większej roli w tych organizacjach. Na pewno przynależność do nich ułatwiała mu kontakty z wydawnictwami niemieckimi, francuskimi czy anglojęzycznymi, gdyż interesów pisarza strzegło izraelskie Stowarzyszenie Autorów, Kompozytorów i Wydawców Muzyki $(\text { ACUM })^{16}$. Niemniej w dossier pisarza w Archiwum Pisarzy Hebrajskich jest kilka listów, lecz żaden z nich nie został napisany w języku hebrajskim, i także nic poza tym, co poświadcza fakt, że nie czuł on potrzeby potwierdzania swojej obecności w izraelskiej przestrzeni literackiej. Również w archiwum Wygodzkiego, złożonym w Bibliotece Zakładu Narodowego im. Ossolińskich we Wrocławiu, nie ma zbyt wielu świadectw jego działalności twórczej skierowanej do hebrajskiego odbiorcy. W latach 1970-1972 pisarz był redaktorem działu literatury polskiej w Encyclopaedia Judaica ${ }^{17}$. W przekazanych przez Wygodzkiego do biblioteki teczkach znajduje się kilka haseł osobowych, traktujących o pisarzach polskich, pisanych w języku polskim, oraz tekst dotyczący jego książki Zatrzymany do wyjaśnienia, lecz nic poza tym. Prawdopodobną przyczyną tego stanu rzeczy było to, że artykuły przeznaczone dla prasy izraelskiej,

${ }^{13}$ M. Dor, Ha-tachana ha-achrana [Ostatni przystanek], przekł. M. Stankiewicz, Maariv 1971 nr 352, s. 68. Wspólnym znajomym był najprawdopodobniej Josef Chrust, thumacz utworów na język hebrajski Wygodzkiego, pracownik „Maariv”.

14 Samuel Josef Agnon, właśc. Szmuel Josef Czaczkes (1888-1970), prozaik, laureat Nagrody Nobla w dziedzinie literatury za rok 1966. Autor powieści i opowiadań obrazujących środowisko chasydzkie na przełomie XIX i XX wieku oraz współczesny mu Izrael.

${ }^{15}$ M. Dor, Ha-tachana ha-achrana, s. 68.

${ }^{16}$ ACUM - The Society of Authors, Composers and Music Publishers in Israel (Hebrew: קומפוזיטורים אגודת , לים"ומו ומחברים), związek założony w 1936 r. strzegący praw autorskich twórców zamieszkujących wpierw Palestynę, obecnie Izrael. Organizacja wchodzi w skład Międzynarodowej Konfederacji Stowarzyszeń Autorów i Kompozytorów (CISAC).

17 Encyclopaedia Judaica, wydana w języku angielskim po raz pierwszy w Jerozolimie w latach 1971-1972 w szesnastu tomach przez wydawnictwo Keter w Tel Awiwie oraz w Nowym Jorku przez Macmillan Company. Dodatkowo w latach 1972-1994 wydawano kolejnych dziesięć roczników. Po raz drugi w dwudziestu dwóch tomach ukazała się w 2007 r. 
ukazującej się w języku hebrajskim, drukował potem w polskojęzycznej prasie, a zatem ich przechowywanie uważał za zbędne.

\section{Między trzema językami}

W odniesieniu do opisu sytuacji pisarzy polskich, którzy po wojnie w latach 19461969 wyemigrowali do Izraela, przyjmuje się w Polsce trzy kategorie: pisarz polski, pisarz żydowski i pisarz izraelski. Nimi w swojej kluczowej rozprawie posłużyła się Karolina Famulska-Ciesielska. Przypadek Wygodzkiego pokazuje, jak zawiłe i niejednoznaczne są to określenia i jak zależne od wyboru przez samego pisarza.

Wygodzki nigdy nie stał się pisarzem izraelskim, choć na pewno był żydowskim z uwagi zarówno na tematykę, którą się zajmował, jak i powodu trwałego bytowania w języku jidysz. Sprawdził się dobrze jako tłumacz dzieł tworzonych w dwóch językach: jidysz i niemieckim. Jidysz, język Żydów aszkenazyjskich, był jego pierwszą mową — loszn mame [język matki]. Jednak z czasem w domu rodzinnym o silnie syjonistycznej proweniencji dominować zaczął, wbrew oczekiwaniom, język polski ${ }^{18}$. Dość szybko, jako kilkunastolatek, Wygodzki właśnie ten język uznał za jedyny, w jakim chciał pisać. Co więcej - nie zawsze przyznawał się do znajomości języka jidysz, czego przykładem jest ankieta członkowska Związku Literatów Polskich z 1963 r., kiedy to w rubryce „Znajomość języków obcych” wpisał: „niemiecki (biegle w mowie i piśmie)"19. Zapis ten można interpretować dwojako. We wcześniej wypełnianych ankietach literackich i partyjnych Wygodzki wpisywał jako języki obce: jidysz oraz niemiecki. Pisarz uznawał bowiem, że polski jest mową, w której budował swoją tożsamość egzystencjalną, kulturową i społeczną. Zatem w tym rozumieniu jeden $\mathrm{z}$ języków żydowskich, którym na co dzień posługiwali się bliscy, przeszedł z kategorii „Swój” na „obcy”. To przesunięcie stało się kwintesencją wyboru, określało Wygodzkiego jako człowieka i pisarza, a jednocześnie stało się powodem do samowykluczenia się z narodu, do którego poprzez urodzenie przynależal. Uznanie mowy rodzinnej za obcą - to wykreślenie cząstki samego siebie, ukrycie nie tylko przed innymi, lecz głównie przed samym sobą swojego osadzenia $\mathrm{w}$ danej tradycji oraz kulturze. $\mathrm{W}$ tym poniekąd dziwnym, acz syjonistycznym domu, w którym ojciec walczył o język hebrajski i utworzenie Erec Israel, a trzech z jego czterech synów działało w nielegalnej Polskiej Partii Komunistycznej, mówiono w trzech językach, a oprócz tego wszyscy: „Jadali chałę i rybę, rosół z makaronem, ale i szynka nie była im obca, i kabanos. Sądzi [Wygodzki], że najsmaczniejsza szynka jest w Jom Kippur" ${ }^{20}$. W okresie przedwojennym jako pisarza nie interesowały go zagadnienia dotyczące stricte świata żydowskiego. Jako komunista zwalczał zło, które niszczyło wszystkich ludzi, niezależnie od ich pochodzenia i narodowości. Wygodzki jako literat stanął w opozycji do rodzimej kultury. Dopiero doświadczenie Zagłady zweryfikowało jego samookreślenie się w świecie. Choć też niejednoznacznie ${ }^{21}$. Brak wpisu języka jidysz do rubryki ,języków obcych” w 1963 r. można by potraktować jako zaprzeczenie faktu, że już wtedy był thumaczem

${ }^{18}$ Syjoniści walczyli o uznanie języka hebrajskiego jako narodowego Żydów. Jidysz był synonimem diaspory — rozproszenia i niewoli.

19 Archiwum Akt Nowych, Teczka osobowa: Stanisław Wygodzki, sygn. 15191, Ankieta członkowska Związku Literatów Polskich, k. 19

${ }^{20}$ A. Tuszyńska, Kilka portretów z Polska w tle. Reportaże izraelskie, Gdańsk 1993, s. 56.

${ }^{21}$ Problem ten głębiej przedstawiony zostanie w książce dotyczącej życia i twórczości Stanisława Wygodzkiego, która ukaże się w tym roku. 
m.in. utworów Efroima Kaganowskiego, Szolem-Alejchema czy Zalmana Wendrowa ${ }^{22}$. Powodów mogło być kilka. Niewątpliwie jedna przyczyn takiego postępowania miała podłoże polityczne - chciał mocno zaznaczyć swoją wyłączną przynależność do środowiska polskich pisarzy. Tę interpretację wzmacniają podane w ankiecie „polskie” imiona i nazwiska jego rodziców. Przekłady były tylko ucieczką od braku weny twórczej, co podkreślił w jednym $z$ wywiadów ${ }^{23}$. Jednak z drugiej strony mógł być to komunikat, że język jidysz przestał być językiem obcym, a na powrót stał się rodzimym. Mimo że nie tworzył w tym języku własnych utworów, to przecież poprzez jego znajomość otwierał polskiemu czytelnikowi możliwość wejścia w świat dawnych żydowskich mieszkańców Polski (utwory Kaganowskiego i Asza). Przekład zawsze zawiera w sobie doświadczenie oraz wiedzę tłumacza. A on — odwoływał się do tych nabytych w rodzinnym domu. Wygodzki wybierał takie utwory, które poprzez tematykę były bliskie jemu samemu. Być może pisarz chciał przesunąć język jidysz ponownie w strefę „swojskości”, wskazać, że tak naprawdę funkcjonował, choć na różnych poziomach oraz w odmiennych rolach, w dwóch językach i w każdym z nich wyrażał pewną cząstkę samego siebie. Niemniej podkreślić należy, że w oficjalnych ankietach nie wpisał języka jidysz jako rodzimego. Jego znajomość okazała się też mało istotną w Izraelu, państwie, które budowało swoją tożsamość w oparciu o język hebrajski. Wygodzki od przyjazdu do Izraela związał się z „Maariv”24, wtedy jednym z najpoczytniejszych dzienników izraelskich. Jako współpracownik pisał po polsku felietony dotyczące polskich pisarzy — czy ogólniej — polskiej kultury, te zaś następnie przekładano na język hebrajski.

Wygodzki stał się zatem w dużej mierze „nieobecnym” pisarzem w kraju, w którym przyszło mu żyć dwadzieścia pięć lat...

\section{Polski publicysta w Izraelu}

Niemoc bezpośredniego funkcjonowania w języku hebrajskim sprawiła, że jedynym miejscem, w którym mógł w pełni zaistnieć, okazały się izraelskie czasopisma, wydawane w języku polskim ${ }^{25}$. Nie było ich zbyt wiele, w przeciwieństwie do ludzi pióra. Kiedy przybył w 1968 r. do Tel Awiwu, tworzyły je środowiska już ukształtowane i ukierunkowane politycznie $^{26}$, a ostatni duży napływ olim w 1968 r. z Polski co prawda dokonał pewnej rewolty, lecz nie aż tak wielkiej, jak tego nowi przybysze oczekiwali. W książce Ewy Kossewskiej znajduje się anegdota, którą przytoczyła Anna Ćwiakowska ${ }^{27}$ :

${ }^{22}$ Zob.: E. Kaganowski, Warszawskie opowiadania, Warszawa 1958; Szolem-Alejchem, Motel, syn kantora, Warszawa 1958; Z. Wendrow, Opowiadania z przeszłości, Warszawa 1962 (na karcie tytułowej polskiego thumaczenia zamieszczono imię i nazwisko Dawid Wendrowski). W 1963 r. Wygodzki pracował już nad kolejnym przekładem opowiadań z języka jidysz Szaloma Asza. Ukazały się w Warszawie w 1964 r.

${ }^{23}$ Zob.: M. Szypowska, Rozmowa ze Stanisławem Wygodzkim, Stolica 1958 nr 27, s. 16.

24 „Maariv” [hebr. wieczór], dziennik założony w 1948 r., jego pierwszym redaktorem naczelnym był Ezriel Carlebach. Politycznie połączony jest z tzw. partiami centrum, które występują przeciwko obecnej władzy. Do lat 80 . był największym organem prasowym w Izraelu.

${ }^{25}$ Zob. więcej m.in.: R. Löw, Ostatki polskie. Rzecz o izraelskiej prasie w języku polskim, Zeszyty Literackie 1994 z. 48, s. 152-155; A. Klugman, Spojrzenie wstecz, Łódź 2000; K. Adamczyk, Doświadczenia polsko-żydowskie $w$ literaturze emigracyjnej; K. Famulska-Ciesielska, Polacy, Żydzi, Izraelczycy; E. Kossewska, Ona jeszcze mówi po polsku.

${ }^{26}$ Zob.: E. Kossewska, Ona jeszcze mówi po polsku.

${ }^{27}$ Anna Ćwiakowska (ur. 1925), pisarka, publicystka i thumaczka z literatury hebrajskiej. Niestety udało mi się do niej dotrzeć bardzo późno, zatem nasze telefoniczne rozmowy były 
W rozmowie ze Stanisławem [Wygodzkim] wpadłam na idiotyczny — jak po czasie zrozumiałam - pomysł, żeby mu zaproponować wydawanie nowego pisma w Izraelu, było wtedy z mojej emigracji kilku dziennikarzy z Polski. Ależ Wygodzki się zdenerwował! I dość mocno mnie „obrugał”28.

Ćwiakowska jest o osiemnaście lat młodsza od Wygodzkiego. Jako kobieta w pełni sił wymarzyła sobie, że w nowej rzeczywistości łatwo powróci do zawodu, będzie, jako dziennikarka, rozmawiała z ludźmi o podobnym doświadczeniu egzystencjalnym, a tym, którzy nie znali realiów Polski za rządów Władysława Gomułki, przedstawi na łamach gazety obraz komunistycznej rzeczywistości. Oburzenie Wygodzkiego mogło być spowodowane zwykłą kalkulacją, wedle której raczej niemożliwym było utworzenie organu prasowego w świecie uporządkowanym i w pełni podporządkowanym władzy. Po pierwsze, dla rządu izraelskiego funkcjonowanie gazet w językach obcych było procesem przejściowym, pozwalającym nowo przybyłym emigrantom z różnych zakątków świata na lepszą i sprawniejszą asymilację. Tytuły raczej zamykano lub łączono, tak, aby przyśpieszyć proces wchodzenia olim w język hebrajski. Po drugie, pisarz nie był pewny swojego statusu. Myślę, że nie czuł się komfortowo, gdyż cały czas ciążyło na nim odium pisarza komunistycznego, który swoją twórczością wzmacniał dekrety, rozporządzenia oraz zalecenia Partii. Żydzi z Polski, którzy przybyli do Izraela w latach 40. i 50. XX w., z pewną ostrożnością podchodzili do emigrantów 1968 r., szczególnie gdy byli to ludzie związani mocno z systemem komunistycznym. Tak też postrzegano Wygodzkiego. Jego pragnienie stworzenia nowej gazety mogło zostać przez niektórych odczytane jako chęć wybicia się ze swoimi poglądami. A on był wtedy człowiekiem o pękniętej osobowości, z trudem akceptował otaczający świat, nie potrafił znaleźć wśród rozgoryczenia swojego miejsca na literackiej mapie Izraela, może nawet nie chciał... choć nie przyznawał się do tego:

Pytam [Mosze Dor], czy nie odczuwa braku czytelników znających język, w którym pisze swoje opowiadania i wiersze. „Nie”, odpowiada Wygodzki powoli, ,to też kwestia wieku. Już nie jestem w wieku, w którym pisarz szuka czytelników lub sławy. Te wiersze, które zostały teraz opublikowane w Londynie, napisałem częściowo już w Izraelu i były one publikowane w czasopismach, ale nie myślałem o książce. Nie myślałem o czytelniku, tylko o sobie. Pisałem je dla siebie. Mam chęć i myślę o napisaniu dodatkowych wierszy, ale nie myślę o czytelnikach, którzy czekają na mnie tak, jak myśli młody lub początkujący pisarz. Nie czekają na mnie i ja nie czekam. To smutne, ale tak jest ${ }^{29}$.

Wygodzki, opuszczając Polskę, był świadom, że utracił to, co dla pisarza jest najcenniejsze - odbiorcę, który przez mowę, empirię i wiedzę czuł wspólnotę z twórcą. Ich światy spotykały się, dokonywały weryfikacji, ścierały się poglądowo, lecz miały wspólną najważniejszą podstawę — język. W grudniu 1967 r. Wygodzki otrzymał od władz polskich dokument podróży serii HA nr 0051483, ważność, którego na wszystkie kraje Europy i poza nią trwała do 4 kwietnia 1968 r. i wedle którego: „Posiadacz niniejszego dokumentu podróży nie jest obywatelem polskim" ${ }^{30}$. Status bezpaństwowca znikł w chwili, gdy Wygodzcy wylądowali na lotnisku w Izraelu. Jednak w odniesieniu

dużym wysiłkiem dla p. Anny. Pozyskałam od niej kilka wartościowych informacji, ale zazwyczaj mówiła, że już wielu spraw nie pamięta lub nie jest pewna.

${ }^{28}$ E. Kossewska, Ona jeszcze mówi po polsku, s. 229.

${ }^{29}$ M. Dor, Ha-tachana ha-achrana, s. 69.

${ }^{30}$ Archiwum Biblioteki Zakładu Narodowego im. Ossolińskich. Archiwum Stanisława Wygodzkiego (dalej: ZNO ASW), teczka nr 18192/III, papiery osobiste i rodzinne Stanisława Wygodzkiego, s. 28-29. 
do kondycji egzystencjalnej i literackiej pisarza trwał on do końca jego dni. Nie czekał na czytelnika, gdyż nie mógł odnaleźć nikogo, kto zrozumiałby jego wybory, kto wiedziałby, że wyjeżdżając do Izraela, wybrał mniejsze zło. I to nie w perspektywie politycznej czy literackiej, lecz osobistej. Ta świadomość wzmocniła w nim poczucie samotności. Wygodzki opowiadał w swoich wierszach o samym sobie, lecz jego losy nie były tożsame ani $\mathrm{z}$ hebrajskim czytelnikiem ukształtowanym w innym świecie wartości i doświadczeniu historycznym, ani z polskim emigrantem bytującym w Londynie czy Paryżu, ani, na koniec, z żydowskimi tułaczami, którzy wraz z nim zawitali w Erec Israel. Z każdym z nich coś go łączyło, ale i dzieliło. Różnica była czasem o wiele większa, niżby się zdawało, powodowała izolację i uniemożliwiała pełne bycie w gronie tych lub tamtych. I nie były tego przyczyną odległości geograficzne czy mentalne. W pewnym momencie okazało się bowiem, że to nie fizyczność, a rodzaj doświadczenia egzystencjalnego stawiał pisarza poza kręgiem polskich, żydowskich i izraelskich spraw.

Wygodzki w marcu 1968 r. na łamach „Maariv” zwrócił się do hebrajskiego czytelnika, prezentując mu losy powieści Zatrzymany do wyjaśnienia ${ }^{31}$. W tym samym czasie, publikując pierwszy artykuł w „Przeglądzie Izraelskim”, opisywał wydarzenia związane z zawieszeniem spektaklu Mickiewiczowskich Dziadów w reżyserii Kazimierza Dejmka ${ }^{32}$. Wygodzki jako publicysta debiutował w Izraelu równolegle w dwóch językach, lecz w żadnym nie czuł się dobrze. Nie odnajdywał się w prasie hebrajskiej — dlatego, że nie mógł sam bezpośrednio zwrócić się do odbiorców. Bariera językowa okazała się bowiem poważniejsza, niż sądził:

człowiek, który w wieku 60 lat opuszcza kraj, w którym się urodził, musi mieć ku temu bardzo głębokie powody. Uczyniłem to nie posiadając zawodu, nie znam hebrajskiego, a gdybym znał, kto w takim wieku zaczyna pisać w języku obcym? ${ }^{33}$

Pomimo głośnych i poniekąd oczekiwanych deklaracji, dla Wygodzkiego jego nowa „spóźniona ojczyzna”34, jak nazwał Izrael w mowie dziękczynnej za wręczenie państwowej nagrody im. prezydenta Zalmana Szazara, zawsze pozostała mu obca. Może w początkowej fazie pobytu w Izraelu marzył o zmianach, aczkolwiek dla kogoś, kto całe dotychczasowe życie tworzył w języku polskim, były one niepomiernie trudne. W języku hebrajskim ukazało się kilkanaście jego utworów literackich. Wygodzki miał dużo szczęścia, gdyż wspierali go dwaj świetni tłumacze, Josef Chrust i Benjamin Tene. Pierwszy z nich przetłumaczył nie tylko utwory literackie, m.in. powieść Zatrzymany do wyjaśnienia, opowiadania składające się na tom Bchor satan (np. Szatanek, Prośba starozakonnego, Rondo, Koncert życzeń, Futro), ale i artykuły ukazujące się w „Maariv” pomiędzy 23 sierpnia 1968 a 16 lipca $1976 \mathrm{r}^{35}$ Tene współtworzył z Wygodzkim drugi z tomów Bemachwo, na który złożyły się opowiadania, m.in.: Dokąd

${ }^{31}$ ZNO ASW, teczka nr 18201/II, s. 25-29, ,Maariv” 15.03.1968 - oryginał w języku polskim.

${ }^{32}$ S. Wygodzki, Niezwykłe widowisko, Przegląd Izraelski 1968 nr 995, s. 2. Redakcja zmieniła tytuł artykułu, zaznaczając, że autor nazwał go Hańba im!

${ }^{33}$ ZNO ASW, teczka nr 18219/II, Korespondencja S. Wygodzkiego, Listy, bruliony i kopie listów do różnych osób. Lit. A-Z, k. 64, list Stanisława Wygodzkiego do Karla Dedeciusa z 31 grudnia 1975.

${ }^{34}$ ZNO ASW, teczka nr 18192/III, Papiery osobiste i rodzinne Stanisława Wygodzkiego, k. 193, Mowa po wręczeniu państwowej nagrody im. prezydenta Zalmana Szazara.

35 Por.: ZNO ASW, teczka nr 18219/II, Korespondencja S. Wygodzkiego, Listy, bruliony i kopie listów do różnych osób. Lit. A-Z, k. 73-74, listy Stanisława Wygodzkiego do prof. Gadalia Ellkoshi z grudnia 1977. 
oczy poniosa, Człowiek z wózkiem, Powróz, Błogosławione niech będa ręce ${ }^{36}$. Recepcja utworów Wygodzkiego była raczej skromna. Ci bowiem, których łączyła z nim wspólnota doświadczenia, czytali je po polsku, pozostali traktowali je jako jeden z wielu przekazów o Holokauście. W świadomości hebrajskich odbiorców Wygodzki stał się jednym z wielu, którzy pisali o Zagładzie. Okazało się bowiem, że nie tylko należało mówić w danym języku, lecz jeszcze w nim myśleć, aby dotrzeć do większego grona krytyków czy czytelników, a tego Wygodzki nie potrafił i nie chciał, to czyniło go tak oddalonym od kraju, w którym zamieszkał. Cytowane powyżej słowa pisarz skierował w 1975 r. do Karla Dedeciusa. Wygodzki od siedmiu lat mieszkał w Giwataim i coraz mocniej przekonywał się, że nie umie i nie może tworzyć w innym języku niż polski, bo tylko w nim zdoła opowiedzieć o sobie, o ludziach i całym bagażu doświadczeń, jakie obserwował, jakie stały się udziałem jego oraz innych w tym zbyt tragicznym i burzliwym wieku XX.

W prasie polskojęzycznej pisarz początkowo nie wzbudził entuzjazmu. Przez sześć lat związany był się z „Przeglądem Izraelskim”, lecz współpracę rozpoczął dopiero w 1970 r. i trwała ona do końca 1975 r. Najprawdopodobniej przerwana została z powodu zmian w składzie redakcji. W tym samym okresie z pismem rozstało się kilku czołowych jego publicystów, m.in. Krystyna Bernard czy Dawid Lazar, zatem ludzie, z którymi Wygodzki się przyjaźnił i których cenił. W latach 70. próbował nawiązać współpracę z „Nowinami i Kurierem”, lecz, jak wyznał w liście do Tamary KarrenZagórskiej ${ }^{37}$, redagującej wspólnie z mężem „Tydzień Polski”: „Do «Nowin» NIE napiszę, moje pióro za słabe dla nich"38. Famulska-Ciesielska podkreśliła tragedię, jaka narodziła się w sercach pisarzy, wynikającą z utraty polskiego odbiorcy. Przywołane zdanie Wygodzkiego otwiera jednak nową perspektywę badań, jaką stwarza opis walki o czytelnika-emigranta. Było to nader trudnym zadaniem, co poświadczają wszystkie działania podejmowane przez pisarza, a łączące się $\mathrm{z}$ jego funkcjonowaniem $\mathrm{w}$ pismach emigracji paryskiej, londyńskiej i izraelskiej. Niemniej jednak walczył wytrwale o możliwość zaistnienia. Trudno omówić tu wyczerpująco owo zagadnienie. Niemniej warto przywołać kilka spostrzeżeń. Wygodzki jako publicysta wciąż balansował, nigdy nie mógł być pewny przyszłości. Nie należał do składu redakcji żadnego z pism, był wyłącznie ich współpracownikiem, chwilami dosyć płodnym, lecz nieustannie zabiegającym o druk swoich artykułów lub utworów literackich. W przestrzeni izraelskiej kolejnym miejscem, w którym się zadomowił, były „Nowiny Kurier”. Pomiędzy 1976 a 1980 r. publikował w nich regularnie. Potem, z racji zmian i coraz gorszego stanu zdrowia, jego teksty pojawiały się coraz rzadziej ${ }^{39}$. Niemniej były obecne aż do jego śmierci, a gdy zmarł w maju 1992 r., poświęcono mu artykuły krytyczne i opublikowa-

\footnotetext{
${ }^{36}$ Prócz wymienionych należy wspomnieć o przekładzie książeczki dla dzieci pt. Odwiedzita mnie żyrafa [Bikra ecel ha-żirafa, 1973] Andy Amir. W Londynie w 1987 r. ukazał się dwujęzyczny polsko-hebrajski tomik Wybór poezji. Joman ahawa [Pamiętnik miłości], thum. na hebr. H. Paruz.

37 Tamara Karren-Zagórska (1913-1997), poetka, pisarka, krytyk literacki i teatralny. Pierwszym jej mężem był Roman Brandstaetter, drugim zaś Wacław Zagórski, oficer Armii Krajowej, dziennikarz, redaktor naczelny londyńskiego tygodnika „Tydzień Polski”.

38 AE, Archiwum Tamary Karren, sygn. AE/TK/XVIII, list Stanisława Wygodzkiego do Tamary Karren-Zagórskiej z 13 stycznia 1972.

${ }^{39}$ Najczęściej w kontekście Zagłady; były to numery upamiętniające wybuch powstania w getcie warszawskim, jego zniszczenia czy w szerszym kontekście wymordowania Żydów w czasie drugiej wojny światowej.
} 
no nie tylko jego wiersze, ale też utwory dedykowane mu przez innych poetów ${ }^{40}$. W sumie artykułów Wygodzkiego uzbierało się dosyć, aby móc postawić tezę, że zamykał się w dwóch tematach: rozrachunku z komunistyczną Polską oraz analizie literackiego zapisu doświadczenia związanego z Zagładą. Oczywiście znajdują się i takie teksty, które łamią tę regułę, niemniej są to sporadyczne wypadki, kiedy pisarz mówi o sobie lub o przedwojennej Polsce.

Epilog zabiegów pisarza o druk własnych utworów publicystycznych i literackich znalazł swoje miejsce w roczniku literackim „Kontury”41. Numer trzeci z roku 1992 przygotowano tak, aby uczcić 85. rocznicę urodzin Wygodzkiego. Pismo ukazało się tuż po jego śmierci, redaktorzy zdążyli tylko dodać krótką adnotację:

Żegnamy wielkiego poetę, prozaika,

szlachetnego i odważnego człowieka,

nierozerwalnie związanego z losem Żydów polskich ${ }^{42}$.

W tomie zawarto jego utwory poetyckie ${ }^{43}$, wypowiedź $O$ samym sobie ${ }^{44}$ oraz krótki tekst Krystyny Bernard-Statler Dla Stanisława Wygodzkiego ${ }^{45}$. Literackie środowisko chciało uświetnić jubileusz pisarza, niestety zmarły w nocy z 8 na 9 maja Wygodzki nie dożył tego momentu. Jeszcze kilkakrotnie na łamach pisma przedrukowano jego wiersze, przekłady z poezji jidysz i niemieckiej czy korespondencje ${ }^{46}$. Walczono o to, aby pamięć o pisarzu przetrwała, gdyż, jak w 1995 r. zauważyła Bernard-Statler:

DOPIERO 3 lata minęły od śmierci Stanisława Wygodzkiego. A już taka cisza po Nim, po obu brzegach życia poety: na odległym, polskim brzegu i tu, blisko Giwataim. Nie przerwał tej ciszy ani Dzień Pamięci o nienawiścią i ogniem spopielonych Żydach; ani wrzawa pośpiesznego (50-lecie zakończenia wojny) kłamliwego rewidowania powojennego bilansu po stronie bitych i bijących. (Choć wrzawa ta z pogranicza politycznej jest groteski).

I mimo to cisza. Przejmująca. Dławiąca cisza nie pamięci o Poecie, który cały był pamięcią o żydowskim losie. W kraju, który wybrał na ostatnią przystań swego wygnańczego życia. Cisza o Nim totalna, nawet w dniach rocznicowej pamięci o zbrodni rasizmu nie pojawił się ani jeden Jego poetycki załącznik do prawnego aktu oskarżenia o zbrodnie hitlerowskiego ludobójstwa.

DOPIERO 3 lata minęły od śmierci Stanisława Wygodzkiego. Pośpieszna, marnotrawcza niepamięć boli - oburza - zawstydza ${ }^{47}$.

${ }^{40}$ Zob.: Nowiny Kurier 15.05.1992, s. 13.

41 „Kontury. Wybór prozy i poezji autorów piszących po polsku w Izraelu”, ukazywały się w latach 1988-2006, redaktorem naczelnym był Ryszard Löw, wydawcą zaś Związek Autorów Piszących po Polsku w Izraelu. Więcej o piśmie: P. Tański, „,Kontury”-izraelskie pismo literackie, Archiwum Emigracji. Studia - Szkice - Dokumenty 2000 z. 3, s. 301-307.

${ }^{42}$ Kontury 1992 z. 3, s. 7.

${ }^{43} \mathrm{Z}$ tomów Pamiętnik miłości (Londyn 1983) oraz Pożegnanie (Londyn 1979).

${ }^{44}$ O sobie samym, Kontury $1992 \mathrm{nr}$ 3, s. 16-22, przedruk z: Emigranci o sobie: Stanistaw Wygodzki, Arka (Kraków) 1986 nr 16, s. 94-98. Wcześniej przedrukowano wypowiedź w: Kurier-Nowiny (Tel Awiw) 1987 nr 7, s. 4 i 6.

${ }^{45}$ K. Bernard-Stattler, Dla Stanisława Wygodzkiego, Kontury 1992 nr 3, s. 23.

46 „Z bardzo daleka, z bardzo bliska”. Z korespondencji Stanisława Wygodzkiego i Andrzeja Kuśniewicza, listy wybrała i przypisami opatrzyła K. Bernard-Statler, Kontury 1995 nr 6, s. 14 27; Listy do Anny Frajlich, Kontury 1998 nr 9, s. 49-60.

${ }^{47}$ K. Bernard-Stattler, Już? Dopiero? - Trzy lata, Kontury 1995 nr 6, s. 9. 


\section{Zwrot ku polskiej emigracji}

W drodze do Tel Awiwu Wygodzcy zatrzymali się w Wiedniu, gdzie wysłannicy Radia Wolna Europa poprosili go o wywiad, w którym wyjaśniłby powody emigracji z Polski. Pisarz nie wyraził zgody i szybko udał się w dalszą podróż. Jan NowakJeziorański, gdy Wygodzki ochłonąwszy, skontaktował się z nim w sprawie współpracy, przypomniał mu jego postawę na wiedeńskim dworcu kolejowym:

Chcieliśmy nawiązać z Panem kontakt w czasie krótkiego pobytu w Wiedniu. Nie był Pan wówczas do tego skłonny, ale zdaję sobie sprawę z tego jak wielkim wstrząsem musiał być dla Pana wyjazd z Polski i staram się zrozumieć osobistą tragedię ludzi, którzy znaleźli się w Pana położeniu. Nie mam więc do Pana żalu o to, że w Wiedniu nie mogło dojść do dłuższej rozmowy między Panem a kimś z naszego Zespołu ${ }^{48}$.

Pisarzowi udało się zamieścić kilka tekstów w periodyku RWE „Na Antenie”, lecz dobre relacje osobiste pomiędzy Wygodzkim a Jeziorańskim nie przełożyły się na większą współpracę literacką. Pisarz jednak zaistniał w eterze RWE, wyemitowano kilka audycji, w których przedstawiono teksty napisane specjalnie dla radia lub wiersze $\mathrm{z}$ tomu Drzewo ciemności ${ }^{49}$.

Wygodzki oczywiście skierował się ku Jerzemu Giedroyciowi i paryskiej „Kulturze". Jednak oprócz publikacji Zatrzymanego do wyjaśnienia i spraw związanych z tym wydarzeniem, współpraca też nie ułożyła się dobrze. Artykuły pisarza ukazywały się rzadko. Wygodzki zabiegał o publikację wierszy na łamach pisma, a także wydanie ich tomu, lecz Redaktor „Kultury” odmówił z powodu dużych kłopotów finansowych ${ }^{50}$.

Najszczęśliwszym miejscem dla pisarza okazał się Londyn. Pomiędzy 1969 r. a 1980 utrzymywał stały kontakt z redakcją „Wiadomości”, na łamach pisma drukował przede wszystkim własne utwory literackie, wiersze, opowiadania, ale i recenzje, notki o pisarzach oraz prowadził kolumnę Notatki, która stanowiła kontaminację literackopublicystyczną. W $1972 \mathrm{r}$. rozpoczął trwającą pięć lat współpracę z „Tygodnikiem Polskim”, dodatkiem do „Dziennika Polskiego i Dziennika Żołnierza”. Duży wpływ na Wygodzkiego wywarła znajomość (głównie korespondencyjna) z Jerzym i Tamarą Zagórskimi, lecz niestety całość również zakończyła się nieszczęśliwie dla pisarza, gdyż nie potrafił odnaleźć się w profilu gazety.

W Londynie działało bardzo prężnie wydawnictwo Oficyna Poetów i Malarzy, założone przez małżeństwo Krystynę i Czesława Bednarczyków. Dzięki ich zaufaniu udało mu się wydać powieść Pieskin zostat pisarzem (1973), a także trzy tomy poezji: Drzewo ciemności (1971), Podróż zimowa (1975) i Pożegnanie (1979). Było to ostatnie wydawnictwo, z którym związał się Wygodzki, choć potem jeszcze w Warszawie w $1990 \mathrm{r}$. wydano tom zawierający jego wiersze z trzech wspomnianych zbiorów, zatytułowany bardzo symbolicznie: Pożegnanie, gdyż faktycznie była to ostatnia książka, którą skierował Wygodzki do polskiego czytelnika.

Pisarz był obecny na łamach pism hebrajsko- i polskojęzycznych, lecz jednocześnie nie należał do czołówki najbardziej pożądanych oraz rozchwytywanych autorów.

${ }^{48}$ ZNO ASW, teczka nr 18215/II, Korespondencja S. Wygodzkiego. Listy, bruliony i kopie listów do różnych osób. Lit. O-R, k. 279, Korespondencja z Radiem Wolna Europa, list od Jana Nowak-Jeziorańskiego z grudnia 1968.

${ }^{49}$ Por.: tamże, s. 313-357.

${ }^{50}$ ZNO ASW, teczka nr 18212/II, Korespondencja S. Wygodzkiego. Listy, bruliony i kopie listów do różnych osób. Lit. G-L, k. 81, 85, listy Stanisława Wygodzkiego do Jerzego Giedroycia z 24 lipca i 19 sierpnia 1970. 
Publicystyka Wygodzkiego na emigracji mogłaby zdawać się dość obfita, lecz w opracowaniach, dotyczących tej problematyki, jego nazwisko pojawia się nader rzadko, zapewne duży wpływ na ten stan rzeczy ma fakt, że większość napisanych przez niego artykułów dotyczyła spraw rozgrywających się na bieżąco. Co zgodne jest z poetyką tekstów publicystycznych, dziś jednak powoduje, że są one nieczytelne i aby odnaleźć kontekst spraw, do których pisarz się odwołał, należałoby wertować podręczniki historii XX w. Dezaktualizacja utrudnia ich pełny odbiór. Wygodzkiemu bardziej jednak zależało na publikowaniu swojej poezji i prozy, a z tym miał większe problemy. W jednym z listów kierowanych do niego, Henryk Grynberg napisał:

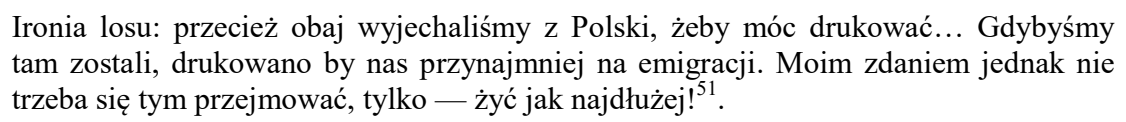

Grynberg pisał te słowa, rozgoryczony postawą jednego z wydawców, który trzymał dwa lata tomik jego wierszy, aż uznał, że go nie wyda, bo atrakcyjniejsi są zakazani poeci krajowi. Wygodzki zapewne, czytając te słowa, uśmiechnął się, gdyż nieobce mu było przekonanie, że wraz z upływem czasu stał się coraz mniej ciekawy zarówno dla hebrajskich, jak i polskich czytelników oraz wydawców. Jednym nie potrafił opowiedzieć o izraelskim życiu, gdyż nie rozumiał go, ale też nie łączyły go z polską emigracją metafizyczne rozterki, ponieważ on pozostał w ukochanej, choć traktującej go po macoszemu Polsce, $\mathrm{z}$ tym widokiem na kopcące śląskie kopalnie, zielone bulwary Warszawy i letnie spacery po nich z Władysławem Broniewskim czy Julianem Tuwimem. W „spóźnionej ojczyźnie” jego głównym orężem było pióro, a kwestia języka, co oczywiste, okazała się prymarną. Wygodzki pozostał na zawsze polskim pisarzem, ponieważ tylko w tym języku potrafił opowiedzieć o wszystkim, co było dla niego ważne, a wiele takich rzeczy było, gdyż jego biografia mocno wpisana jest w największe wydarzenia XX w., szczególnie te dotyczące Polski.

\section{LITERATURA}

Archiwum Akt Nowych, Teczka osobowa: Stanisław Wygodzki;

Archiwum Biblioteki Zakładu Narodowego im. Ossolińskich. Archiwum Stanisława Wygodzkiego;

Archiwum Emigracji Biblioteki Uniwersyteckiej w Toruniu, Archiwum „Wiadomości”;

Archiwum Emigracji Biblioteki Uniwersyteckiej w Toruniu, Archiwum Tamary Karren;

Archiwum Pisarzy Hebrajskich w Tel Awiwie, Wigodski, Yehoshua, Makhon Gnazim, Tel Aviv, $118,69252$.

$\$ 2,500$ Memorial Award given by Bergen-Belsen Group to new Polish immigrant in Israel, JTA Daily News Bulletin 1969 nr 125, s. 3;

K. Adamczyk, Doświadczenia polsko-żydowskie w literaturze emigracyjnej (1939-1980), Kraków 2008;

K. Bernard-Stattler, Dla Stanisława Wygodzkiego, Kontury 1992 nr 3, s. 23;

—, Już? Dopiero? - Trzy lata, Kontury 1995 nr 6, s. 9;

M. Dor, Ha-tachana ha-achrana [Ostatni przystanek], tłum. M. Stankiewicz, Maariv 1971 nr 352, s. 68-69;

${ }^{51}$ ZNO ASW, teczka nr 18212/II, Korespondencja S. Wygodzkiego. Listy, bruliony i kopie listów do różnych osób. Lit. G-L, k. 160, list Henryka Grynberga do Stanisława Wygodzkiego z 24 lutego 1979. 
K. Famulska-Ciesielska, Polacy, Żydzi, Izraelczycy. Tożsamość w literaturze polskiej w Izraelu, Torun 2008;

A. Klugman, Spojrzenie wstecz, Łódź 2000;

E. Kossewska, Ona jeszcze mówi po polsku, ale śmieje się po hebrajsku, Warszawa 2015;

R. Löw, Ostatki polskie. Rzecz o izraelskiej prasie w języku polskim, Zeszyty Literackie 1994 z. 48, s. 152-155;

Pisarz Stanistaw Wygodzki przybyt do Izraela jako nowy ole, Nowiny i Kurier 1968 nr 31, s. 2; M. Szypowska, Rozmowa ze Stanistawem Wygodzkim, Stolica 1958 nr 27, s. 16;

P. Tański, „Kontury” - izraelskie pismo literackie, Archiwum Emigracji. Studia - Szkice Dokumenty 2000 z. 3, s. 301-307;

A. Tuszyńska, Kilka portretów z Polska w tle. Reportaże izraelskie, Gdańsk 1993;

S. Wygodzki, Niezwykłe widowisko, Przegląd Izraelski 1968 nr 995, s. 2.

\section{TO LAST IN LANGUAGE-THE CASE OF STANISLAW WYGODZKI}

Stanisław Wygodzki (1907-1992), a poet, writer, publicist, translator and screenwriter associated in contemporary Polish literary studies with topics concerning the Holocaust. The aim of the article is to provide a general description of an obscure stage of Wygodzki's life and artistic activity which lasted from the writer's emigration from Poland in January 1968 till his death in May 1992. Wygodzki lived in Givatayim, one of Tel Aviv districts, and, as a sixty-year-old man, had to redefine his status as either a Polish writer in exile or a Jewish writer in a new homeland. It is essential to have a closer look at newspapers for which he worked in Israel (Przeglad Izraelski and Nowiny Kurier) and journal published by Polish diasporic communities (Kultura, Wiadomości and Tygodnik Polski).

KEY WORDS: Stanisław Wygodzki; Polish writers in Israel; Polish diasporic literature between 1968 and 1992, Polish press in Israel; Polish immigration press published between 1968 and 1992.

\section{TRWAĆ W JEZZYKU — PRZYPADEK STANISLAWA WYGODZKIEGO}

Stanisław Wygodzki (1907-1992), poeta, pisarz, publicysta, tłumacz, scenarzysta — dziś jego dorobek przypisany jest $\mathrm{w}$ polskich badaniach literaturoznawczych do tematyki związanej z Holokaustem. Celem artykułu jest ogólne opisanie mało znanego etapu jego życia oraz twórczości, który trwał od chwili opuszczenia przez pisarza Polski w styczniu 1968 r. do śmierci w maju 1992 r. Wygodzki zamieszkał w Giwataim, dzielnicy Tel Awiwu, i jako sześćdziesięcioletni mężczyzna musiał określić swój status na nowo: czy jest polskim pisarzem na emigracji, czy pisarzem żydowskim w nowej ojczyźnie. Istotne jest przyjrzenie się ośrodkom, z którymi nawiązał współpracę zarówno w Izraelu („Przegląd Izraelski” i „Nowiny Kurier”), jak i w środowiskach polskiej emigracji („,Kultura”, „Wiadomości” i „Tygodnik Polski”).

SŁOWA KLUCZOWE: Stanisław Wygodzki; polscy pisarze w Izraelu; literatura polska na emigracji 1968-1992; prasa polska w Izraelu; prasa polska na emigracji 1968-1992. 